Original Paper

doi 10.15826/recon.2020.6.2.009

\title{
Chinese and Russian transport corridors and the belt and road initiative: prospects of Sino-Russian cooperation
}

\section{Q. Chen}

Institute of Russia, Harbin Academy of Social Sciences of Heilongiiang Province, China; e-mail: 284748191@qq.com

\begin{abstract}
Relevance. The article discusses mutually beneficial cooperation between Russia and China within the framework of the Belt and Road Initiative and the role of Russia as a key link between China and the Eurasian Economic Union. The relevance of the study is determined by the need for a comprehensive analysis of the current state of transport cooperation between the countries with shared borders (Russia and China) and on a more global level. It is especially important to identify the priority areas of intergovernmental cooperation in the transportation sphere. Research objective. The study is aimed at evaluating the prospects of Sino-Russian transport cooperation in connection with the Belt and Road Initiative. Data and methods. For comparative analysis, we use qualitative and quantitative indicators to consider the current state of Sino-Russian cooperation. Our research draws from the official statistical data of Russia and China and from the findings of the previous studies. Results. The research has shown that there is a steady trend for integration of Russian and Chinese crossborder infrastructure. In particular, the Economic Corridor China-Mongolia-Russia relies on the expansion and modernization of the railway and highway infrastructure. Conclusions. The connection of the Belt and Road Initiative with the Eurasian Economic Union will contribute to transport cooperation between China and Russia. Sino-Russian transport cooperation will develop not only on the state level but also on regional and local levels. The Belt and Road Initiative will enable Russia and China unite their transport infrastructure into a single network. Apart from the transport infrastructure, Sino-Russian cooperation also encompasses other aspects, such as training of specialists in logistics and transportation technologies.
\end{abstract}

\section{KEYWORDS}

crossborder infrastructure, Belt and Road Initiative, container trains, Economic Corridor China-Mongolia-Russia, transport corridor, transport infrastructure, Eurasian Economic Union

\section{FOR CITATION}

Chen, Q. (2020) Chinese and Russian transport corridors and the belt and road initiative: prospects of Sino-Russian cooperation. R-economy, 6(2), 100-110. doi: $10.15826 /$ recon.2020.6.2.009

\section{Китайский и российский транспортные коридоры и инициатива «Один пояс - один путь»: перспективы китайско-российского сотрудничества}

\section{Ц. Чень}

Институт России Академии общественных наук провинции Хэйлунизян, Харбин, Китай; e-mail:284748191@qq.com

\section{АННОТАЦИЯ}

Актуальность. В статье рассматривается взаимовыгодное сотрудничество между Россией и Китаем в рамках инициативы «Один пояс - один путь» и роль России как ключевого звена между Китаем и Евразийским экономическим союзом. Актуальность исследования определяется необходимостью всестороннего анализа текущего состояния транспортного сотрудничества между странами с общими границами (Россия и Китай) и прочими задействованными странами. Особенно важно определить приоритетные направления межгосударственного сотрудничества в транспортной сфере. Цель исследования. Цель исследования - оценить перспективы китайско-российского транспортного сотрудничества в связи с инициативой «Один пояс - один путь» Данные и методы. Для сравнительного анализа мы используем качественные и количественные показатели, чтобы рассмотреть текущее состояние китайско-российского сотрудничества. Наши исследования основаны на официальных статистических данных России и Китая, а также на результатах предыдущих исследований. Результаты. Исследование показало, что существует устойчивая тенденция к интеграции российской и китайской трансграничной инфраструктуры. В частности, (c) Chen, Q., 2020

\section{КЛЮЧЕВЫЕ СЛОВА}

трансграничная инфраструктура, инициатива «Один пояс - один путь», контейнерные поезда, экономический коридор Китай-Монголия-Россия, транспортный коридор, транспортная инфраструктура, Евразийский экономический союз 
экономический коридор Китай-Монголия-Россия опирается на расширение и модернизацию железнодорожной и автодорожной инфраструктуры. Выводы. Связь инициативы «Один пояс - один путь» с Евразийским экономическим союзом будет способствовать транспортному сотрудничеству между Китаем и Россией. Российско-китайское транспортное сотрудничество будет развиваться не только на государственном, но и на региональном и местном уровнях. Инициатива «Один пояс - один путь» позволит России и Китаю объединить свою транспортную инфраструктуру в единую сеть. Помимо транспортной инфраструктуры, китайско-российское сотрудничество охватывает и другие аспекты, такие как подготовка специалистов в области логистики и транспортных технологий.

\section{ДЛЯ ЦИТИРОВАНИЯ}

Chen, Q. (2020) Chinese and Russian transport corridors and the belt and road initiative: prospects of Sino-Russian cooperation. R-economy, 6(2), 100-110. doi: 10.15826/ recon.2020.6.2.009

\section{Introduction}

The Belt and Road Initiative (BRI) is a new strategy of China implemented within the country's more general 'opening-up' policy (Kong, Swallow, \& Thomson, 2020). The Eurasian Economic Union (EAEU) is an international organization comprising post-Soviet countries such as Russia, Kazakhstan, Belarus, Armenia and Kyrgyzstan. Russia is the driving force behind the EAEU, especially the organization's strategic decision-making. The priority goal of the EAEU is to lift the tariff barriers for the member states and create a single economic space, thus increasing the trade turnover between the members (Lukin, 2020). It is planned to connect the space created within the EAEU borders with the space covered by the BRI, which is what makes the EAEU so attractive for China. The BRI in fact is a mechanism of mutually beneficial international cooperation.

In May 2015, China and Russia signed the Joint Declaration on Cooperation in Coordinating the Development of the Eurasian Economic Union and the Silk Road Economic Belt. In May 2018, China and the EAEU signed the agreement on trade and economic cooperation, emphasizing the connection of the BRI with the EAEU as one of its priority areas. Connection of the BRI with the EAEU means that the countries involved in both of these projects will be working together to ensure the economic development, prosperity and stability in Eurasia (Mekhdiev, et al., 2019).

This study is aimed at evaluating the prospects of Sino-Russian transport cooperation in its connection with the BRI. This aim determined more specific objectives of our research. First, we are going to consider the results of Sino-Russian cooperation in the sphere of transportation. Second, we are going to describe priority areas of their cooperation in connection to the plans to integrate the BRI with that the EAEU. Third, we are going to consider the results and prospects of $\mathrm{Si}$ no-Russian cooperation within the framework of the Economic Corridor China-Mongolia-Russia. Finally, we are going to draw conclusions about the current state and prospects of Sino-Russian cooperation in the light of global integration processes.

\section{Theoretical framework and methodology}

This study relies on the method of comparative analysis. To analyze the similarities and differences in Russian and Chinese approaches to transport cooperation, we use quantitative and qualitative indicators.

There is vast research literature on this question. Li (2019) discusses the creation of a railway transport corridor between north-eastern provinces of China and Russia's Far East. Sazonov \& Xiao (2018) point out that the integration of the Chinese-Russian crossborder freight transportation network is crucial for integration of the Asia-Pacific region and conclude that development of the transport system will have a multiplier effect for all the stakeholders.

Problems of transport corridors between Russia and China are discussed by Nan et al. (2017) and Yunhao (2015), who raise the question of uneven distribution of crossborder corridors for freight traffic. Moreover, they consider the problems arising from the fact that Russia is lagging behind China in terms of logistics infrastructure. Yunhao (2015) discusses the role of the Trans-Siberian Railway in creating the international transport corridor and points out that the main challenge in this process is the state of the infrastructure at the railway border crossings, especially the Russian ones connected with the Trans-Siberian Railway. Careful planning of the routes could enhance the capacity of the trade corridors.

Diayu (2017), Balakin (2012) and Labyuk (2016) consider China's participation in international Arctic projects, including the Northern Sea Route. These authors agree that China seeks to gain a more solid footing in the Arctic even though 
it is not an Arctic state. No satisfactory solution, however, has so far been found to the problem of the conflict of interests between China and other countries. Mei (2019), for example, contends that China should take a part in the administration of the Northern Sea Route by ensuring environmental protection in the area, which is in the interests of Russia and China and is in compliance with the Law of the Sea Convention. Xin (2018) focuses on waterborne freight transportation between Russia and China and analyzes the real cases of conflicts arising between the two countries, which leads him to suggest that specific rules of freight transportation should be agreed upon.

Much attention is given to the problems associated with infrastructure construction and economic development of crossborder points in Russia and China. Shuan et al. (2017) discuss the economic and social aspects and problems of Chinese and Russian border regions. Pin (2015) considers the current state and prospects of development of crossborder points in Heilongjiang province and shows that intensification of integration processes will have a positive effect on the development of border regions both in China and in Russia. Yi (2017) suggested creating a cluster of crossborder points to take a full advantage of the strengths of different points and stimulate economic development in Russian and Chinese border regions. Studies of Sino-Russian crossborder cooperation describe different alternatives of its further development.

Although the above-discussed studies provide significant evidence, they mostly highlight separate aspects without giving the full picture of Sino-Russian cooperation. This study applies a more comprehensive approach by taking into account various factors to evaluate the prospects of Sino-Russian transport cooperation in connection with the Belt and Road Initiative.

\section{Results and discussion}

\section{Sino-Russian cooperation in the sphere of international transport corridors: current stage}

In recent years, transport cooperation between Russian and China has been actively developing. The BRI opens new opportunities for cooperation, especially in the light of the future connection of this initiative with that of the EAEU (Wang, Lim, Zhang, Zhao, \& Lee, 2020). At this stage, the following tasks related to the construc- tion of China-Russia transport corridors need to be addressed: first, construct the transport infrastructure; second, develop the already existing cargo routes and open new ones; and, finally, expansion of the two-way transport corridors, turning them into three-way and multi-way transport corridors.

Let us consider each of these tasks in more detail.

The first task is the construction of the transport infrastructure. China and Russia share a long land border. The success of their plans largely depends on whether both countries will be able to elaborate concerted approaches and effective solutions. By connecting the BRI with the EAEU, Russia and China will be able to ensure a stable progress in the construction of their crossborder infrastructure.

Geographically, China-Russia transport corridors can be divided into the transport corridors across the Amur river and the transport corridors connecting China with Russia's Far East.The former include bridges and a cross border cableway.

The idea to build a bridge across the Amur between Blagoveshchensk and Heihe started to be discussed as early as in 1995 but officially its construction was launched only in December 2016. Thus, it can be said that the BRI was a major driving force behind this project. This is the first cable-stayed bridge built in a cold, high-altitude region of China; it is also the first Sino-Russian crossborder highway bridge across the Amur. Russia and China connected their sides of the bridge in May 2019. It was expected that by 2020, the passenger traffic between the two cities would reach $1.4 \mathrm{mln}$ people while the cargo traffic would be up to 3 mln tons ${ }^{1}$. In 2019, the customs in Heihe registered the volume of cargo traffic at the level of 743 thousand tons, which is $28.3 \%$ higher than in $2018^{2}$. The number of people going through the border checkpoints in Heihe exceeded 1 million $^{3}$. After the bridge is fully completed, it will ensure uninterrupted allyear transport connection between Blagoveshchensk and Heihe.

Construction of the cableway across the Amur between Heihe and Blagoveshchensk started in July 2019. It was the first crossborder cable-

${ }^{1}$ https://www.sohu.com/a/319391405 120051348 (date of access: 23.05 .2020$)$

2 https://www.thepaper.cn/newsDetail forward 5577445 (date of access: 23.05.2020)

http:// w w w.h lj.xinhuanet.com/kl$\mathrm{j} / 2019-12 / 21 / \mathrm{c}$ 138648134.htm (date of access: 23.05.2020) 
way between Russia and China. It is planned that the total length of the cableway will be 972 meters while its estimated capacity will be 6 million people a year. The cableway will be put in commission in the second half of 2022, which will stimulate tourism between the two countries ${ }^{4}$. A trip from Heihe to Blagoveshchensk will take no more than 10 minutes. It is predicted that after the cableway is completed, there will be a rise in the number of tourists travelling between the twin cities but also between province Heilongjiang and Amur region. The operation of the cableway does not depend on climatic or seasonal conditions, which means that it can be effective in attracting larger numbers of tourists throughout the year. It should be noted that currently the connection between Blagoveshchensk and Heihe is provided in summer by motor ships sailing along the Amur River and in winter, by a pontoon bridge for cargo and passenger bus transportation.

Construction of transport corridors across the Amur is a major step in crossborder infrastructure development. The crossborder network between Russia and China helps the partner countries create a new international transport corridor

${ }^{4}$ https://rg.ru/2019/11/04/rossiiu-i-kitaj-sviazhet-unikalnaia-kanatnaia-doroga.html (date of access: 24.05.2020) and enables the exchange of specialists and goods (Ryzhova \& Ioffe, 2009).

In the Far East, there are two major projects - international transport corridors 'Primorye-1' and 'Primorye-2', which are a part of the BRI. They are also crucial for the cooperation between the north-eastern provinces of China and Russia's Far East. On 4 July 2017, China and Russia signed the Memorandum of Cooperation for the Development of Primorye 1 and Primorye 2 International Transport Corridors (Fig. 1, 2). Corridors 'Primorye-1' and 'Primorye-2' go through the centre of the Far Eastern Advanced Development Zone of Russia - the free port of Vladivostok, which means that there are 24/7 single window checkpoints available with the single window system, that is, all documents are submitted through a single entry point. Traders can submit documents for shipping goods from China to Russia only once when they cross the Chinese border and there is no need to submit a similar set of documents at the Russian border as Russian customs authorities get access to these documents automatically. It is also planned to introduce an electronic customs declaration system and apply the 'green corridor' principle for smoother border processing.

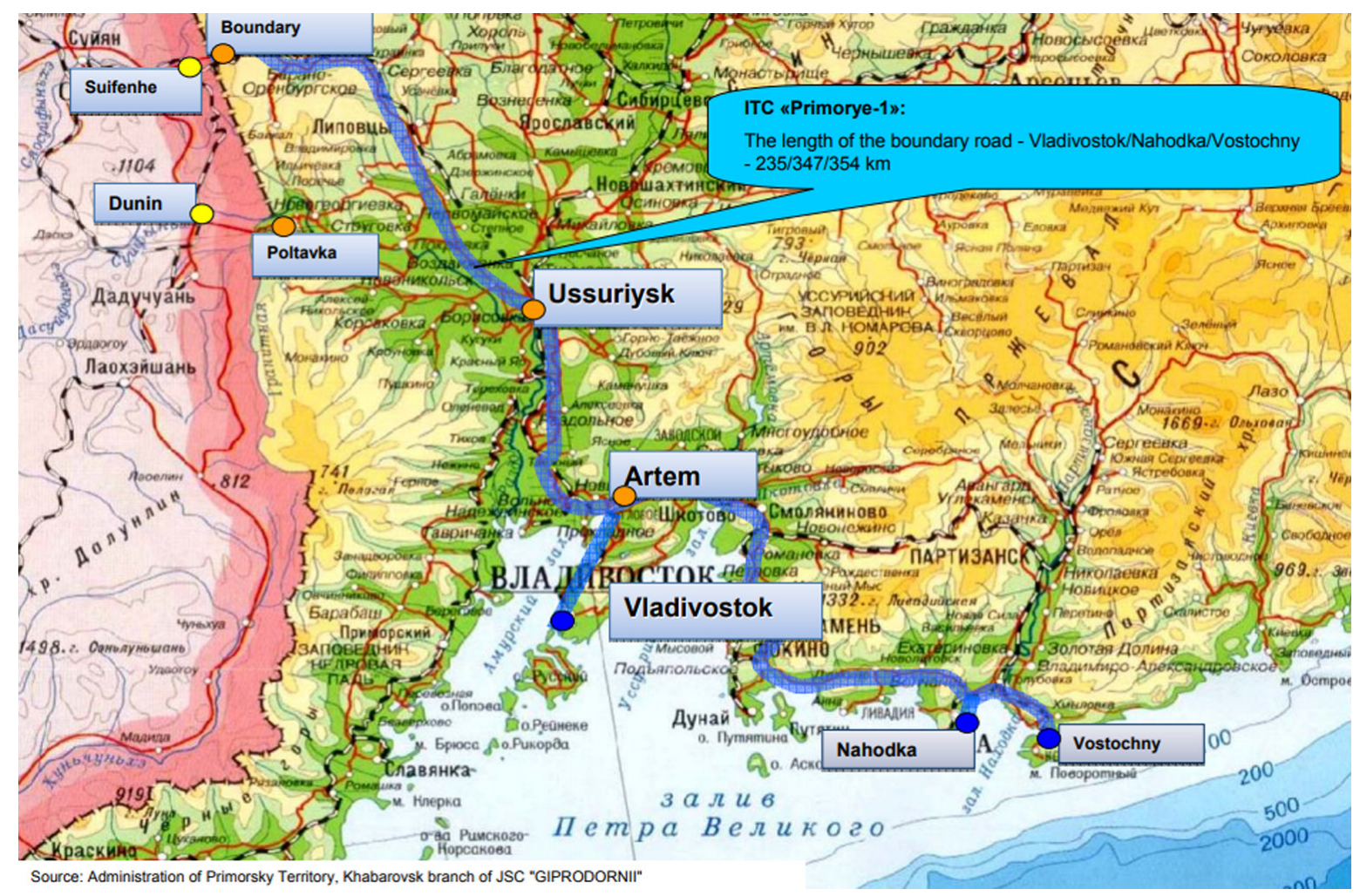

Figure 1. Transport corridor 'Primorye -1'

Source: Administration of Primorye Region 


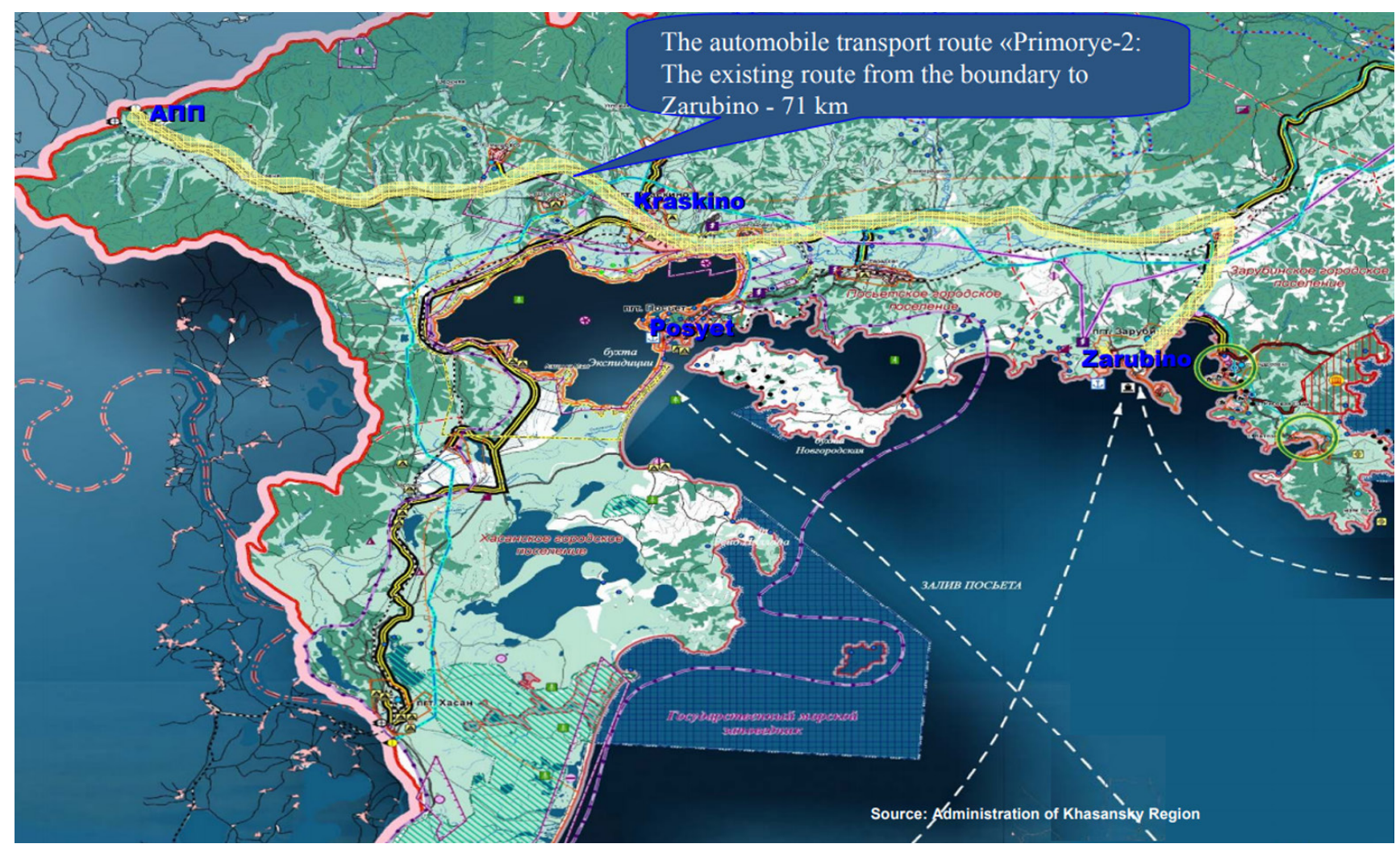

Figure 2. Transport corridor 'Primorye -2'

Source: Administration of Khabarovsk Region

Provinces Heilongjiang and Jilin, which play a key role in Sino-Russian cooperation, are located more than $1,000 \mathrm{~km}$ inland from the sea, which increases the logistics costs. Freight routes 'Primorye-1' and 'Primorye-2' can connect the two provinces with the sea and thus cut the distance of land transportation by $200-500 \mathrm{~km}$, reducing the costs by $10-40 \%$. In the last two years, the volume of freight traffic along 'Primorye-1' corridor has grown 1.8 times - from 2,138 to 3.934 in twenty-foot equivalent units (TEUs) - and along 'Primorye-2', up to 2,145 TEUs ${ }^{5}$.

Second task: development of the already existing cargo routes and opening of new ones. The BRI and EAEU integration sets the bar high for the crossborder logistics network. Both China and Russia are interested in improving the already existing logistics channels and creating new ones.

There are over 40 freight shipping routes between Heilongjiang province and Russian border regions (Bardal, 2014). Harbin is the capital of Heilongjiang province and is crucial to China's interactions with Russia. There is an international cargo route connecting Harbin with Europe (Tjia,

${ }^{5}$ https://www $\cdot$ primorsky.ru/news/164469/ (date of access: 25.05 .2020 )
2020) launched in June 2015, with trains running once a week. Currently container trains arrive from China in Małaszewicze (Poland), Hamburg and Duisburg (Germany), Zeebrugge (Belgium), and Minsk (Belarus). These are among the main international logistics routes created by Heilongjiang province as a part of the BRI. As of August 2019, on Harbin-Europe route, container trains had made 882 journeys and delivered 51,488 TEUs worth 2 billion US dollars ${ }^{6}$. The route was largely intended for exporting Volvo automobiles, high-tech products, textiles and goods of prime necessity from China to Europe and for importing from Europe spare car parts, high-quality goods of prime necessity and timber. Since the railway connection between Harbin and Europe primarily stimulates the development of automotive industry, these trains are commonly referred to as 'car trains'.

Apart from Harbin-Europe trains, in June 2016, the railway between Harbin and Russia was put in commission. In 2019, lines from Har-

6 哈俄班列增开新线路（梅尔基-绥芬河-哈尔滨）顺 利开通, 生活报, 2019-08-13 (The new railway line 'Mylki -Suifenhe - Harbin' was opened for container trains running between Russia and Harbin, Life Daily, 2019-08-13) 
bin to Ekaterinburg and Biklyan were opened. In the same year, a new container train line 'Mylki-Suifenhe-Harbin' was launched. This line specializes on the import of lumber and woodpulp products to China. For more detailed information on Harbin-Russia trains, see Table 1 below.

Table 1

\section{Harbin-Russia container trains}

\begin{tabular}{|l|c|c|c|c|l|}
\hline $\begin{array}{c}\text { Dis- } \\
\text { patch } \\
\text { station }\end{array}$ & $\begin{array}{c}\text { Ter- } \\
\text { minal } \\
\text { station }\end{array}$ & $\begin{array}{c}\text { Date of } \\
\text { the first } \\
\text { depar- } \\
\text { ture }\end{array}$ & $\begin{array}{c}\text { Goods } \\
\text { shipped } \\
\text { via first } \\
\text { train, in } \\
\text { mln US } \\
\text { dollars }\end{array}$ & $\begin{array}{c}\text { Intermedi- } \\
\text { ate } \\
\text { stations }\end{array}$ & $\begin{array}{l}\text { Trans- } \\
\text { ported } \\
\text { goods }\end{array}$ \\
\hline Harbin & $\begin{array}{l}\text { Ekate- } \\
\text { rinburg }\end{array}$ & $\begin{array}{l}12 \text { March } \\
2016\end{array}$ & 10 & $\begin{array}{l}\text { Manzhouli, } \\
\text { Novosi- } \\
\text { birsk, Perm }\end{array}$ & $\begin{array}{l}\text { Spare } \\
\text { car } \\
\text { parts }\end{array}$ \\
\hline Harbin & Biklyan & 11 May & 7.5 & $\begin{array}{l}\text { Manzhouli, } \\
\text { Zabaikalsk, } \\
\text { Irkutsk }\end{array}$ & $\begin{array}{l}\text { Ma- } \\
\text { chinery } \\
\text { and } \\
\text { equip- } \\
\text { ment }\end{array}$ \\
\hline Mylki & Harbin & 13 August \\
2019 & 0.1 & $\begin{array}{l}\text { Khabarovsk, } \\
\text { Suifenhe }\end{array}$ & $\begin{array}{l}\text { Lum- } \\
\text { ber and } \\
\text { wood- } \\
\text { pulp }\end{array}$ \\
\hline
\end{tabular}

Source: compiled by the author based on materials http:// hlj.people.com.cn

* http://hlj.people.com.cn/n2/2016/0312/c22002727919303.html (date of access: 25.05.2020); https://www. sohu.com/a/313335250 99960365 (date of access: 25.05 .2020 ); http://hlj.people.com.cn/n2/2019/0818/c220027-33261006. $\underline{\text { html (date of access: 25.05.2020) }}$

Harbin is an important hub for import of such products as lumber and woodpulp. From Harbin, these products are redistributed to other Chinese cities, which makes it particularly important for Sino-Russian cooperation. After the launch of the railway line between China and Russia, container trains made 352 journeys delivering 25,150 TEUs worth 400 billion US dollars ${ }^{7}$. The route between Harbin and Russia is one of the most important railway routes connecting Eastern China with Europe.

Railway transport provides a regular, nonstop connection between China, Russia and Europe: in comparison with sea transport, railway enjoys a number of advantages, for example, it is independent from weather conditions or seasons, it is secure and there is a low risk of cargo damage. Rail freight transportation is also less costly than air freight. Moreover, the train schedule is also

7 哈俄班列增开新线路（梅尔基-绥芬河-哈尔滨）顺 利开通, 生活报, 2019-08-13 (The new railway line 'Mylki -Suifenhe - Harbin' was opened for container trains running between Russia and Harbin, Life Daily, 2019-08-13) much more reliable, minimizing the risk of delays in delivery. Normally, the transportation time is measured in hours. In addition, container trains can use a modern information platform to provide full monitoring and management of the shipment data, thus enabling the customers to track cargo delivery.

Harbin-Europe and Harbin-Russia container trains use the eastern corridors of the railway routes between China and Europe, which were launched in the period when Sino-Russian cooperation started to develop. Harbin is located in the centre of the international corridor; it is an international logistics centre, which performs a variety of functions such as transportation, storage, customs processing and distribution. The routes Harbin-Europe and Harbin-Russia, together with other routes between Europe and China starting in Guangzhou, Qingdao, Nanjing, Chongqing, Xiamen, and Zhengzhou, form logistics corridors, which play an important role in the Sino-Russian trade and economic cooperation.

Third task: expansion of the two-way transport corridors, turning them into three-way and multi-way transport corridors. The third task is to involve other countries in Sino-Russian cooperation. The international transport corridor 'Primorye-1' is a part of the BRI. It is a land-sea transport corridor connecting North-Eastern Asia and Europe. The China-Mongolia-Russia Economic Corridor has two railway passages in China: one is the Northern Passage, going from Beijing-Hebei through Hohhot to Mongolia and Russia; the other is the Eastern Passage, going from Tianjin through Dalian, Changchun, Harbin, Manzhouli to Russia (Dong et al., 2018). Construction of the China-Mongolia-Russia Economic Corridor requires the implementation of more than 10 plans for integrating the infrastructure of the three countries for unobstructed transborder passage, which includes modernization of railway corridors (see Fig. 3).

A significant event for the China-Mongolia-Russia Economic Corridor project happened in July 2019, when the first meeting of the Joint Committee on the Intergovernmental Agreement on the Asian Highway Network was held and the international highway route going through the three countries was declared officially open. The Agreement outlines measures aimed at ensuring smooth development of the corridor, such as construction and modernization of the highway infrastructure in Russia and Mongolia. 


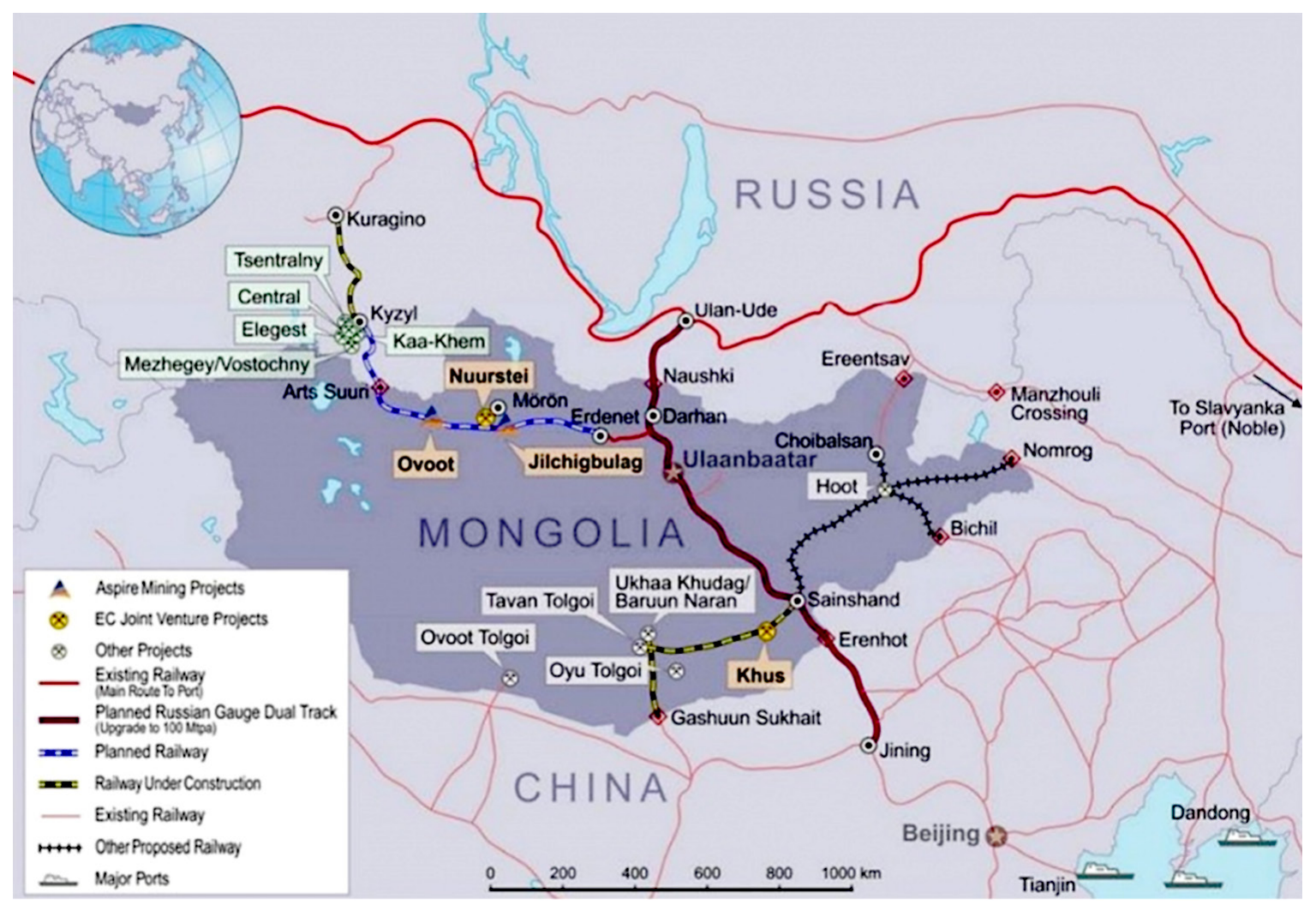

Figure 3. The China-Mongolia-Russia Economic Corridor Source: On-line magazine 'Zolotaya Orda' http://zolord.ru

\section{Priority areas of Sino-Russian cooperation}

Integration of the EAEU with the BRI is linked to Russia and China's efforts to expand their transport cooperation in the three priority areas:

1. Development of Sino-Russian transport cooperation not only on the state level but also on regional and local levels. Russian and Chinese governments attach great significance to integrating the BRI with the Northern Sea Route (NSR) and are going to put their joint effort into using the NSR for building the 'Ice Silk Road'. In 2013, a state Chinese company received permission from the NSR Administration for three passages, which effectively means the start of commercial transportation via the NSR (including container transportation). So far, the company has been using two ships in its operations (Бардаль, 2014). This fact demonstrates that in partnership with Russia, China has real opportunities to become an Arctic economic power.

As a part of the BRI, the first large-scale projet 'Yamal LNG' was launched. This project changed the traditional model of raw material imports to China and created a new model of international cooperation in the energy sphere. On 19 July
2018, two tankers with liquefied natural gas for the first time travelled via the NSR and arrived in China. The voyage took 19 days, which is 16 days less in comparison with the traditional route via the Suez Canal and the Malacca Straits (Zeng, Lu, Lin, Yuen, \& Li, 2020). In 2018, the overall cargo volume via the NSR was 18 million tons, which signifies an $80 \%$ increase in comparison with 2017 (Иньань, 2019). The Russian government predicts that the cargo volume via the NSR will rise to 51 million tons in 2021 and to 80 million tons in 2024.(Lazarev \& Fisenko, 2020). Thus, the Sino-Russian project 'Yamal -LNG' laid the foundation for joint construction of the 'Ice Silk Road'.

As a result of 'Yamal-LNG', there was an increase in the imports of natural gas to China (see Table 2).

As Table 2 illustrates, since 2018, the amount and value of natural gas imports to China have been growing steadily. In 2018 China became the largest importer of natural gas in the world. Increasing gas consumption changes the whole structure of energy consumption in China, which means that the country is gradually switching to cleaner, low-carbon energy materials. Potentially, this could have a serious impact on the global gas 
trade. Russia is the main supplier of natural gas, which makes energy cooperation crucial for the relationship between the two countries.

Table 2

China's natural gas imports in 2016-2019

\begin{tabular}{|r|r|r|r|r|}
\hline Year & $\begin{array}{c}\text { Amount } \\
\text { of natural } \\
\text { gas imports } \\
\text { (mln tons) }\end{array}$ & $\begin{array}{c}\text { Compared } \\
\text { with the } \\
\text { previous } \\
\text { year (\%) }\end{array}$ & $\begin{array}{c}\text { Value of } \\
\text { natural gas } \\
\text { imports (mln } \\
\text { US dollars }\end{array}$ & $\begin{array}{l}\text { Compared } \\
\text { with the } \\
\text { previous } \\
\text { year (\%) }\end{array}$ \\
\hline 2016 & 54.03 & +22.0 & 16.489 & -10.8 \\
\hline 2017 & 68.57 & +26.9 & 23.275 & +41.2 \\
\hline 2018 & 90.39 & +31.9 & 34.480 & +65.3 \\
\hline 2019 & 96.56 & +6.9 & 41.720 & +8.5 \\
\hline
\end{tabular}

Apart from the state-level strategic cooperation, both countries are committed to developing their cooperation on the regional level. In this case, the north-eastern part of China plays the key role in Sino-Russian cooperation: it has a large number of crossborder passage points, it is located in close geographical proximity to Russia and has a long history of cooperation with Russia's Far East in such spheres as agriculture, construction, and transport. The north-east of China participates in the 'Ice Silk Route' project, which includes plans for establishing sea routes to Vladivostok, Zarubino and other ports. Creation of the China-Mongolia-Russia Economic Corridor will, in its turn, accelerate the revival of China's north-eastern provinces and development of Russia's Far East. It is expected that the zone of marginal economy and the zone of resource supply will thus be transformed into experimental regions for resource development and creation of economically developed territories.

2. Projects of transport cooperation and integration of Russian and Chinese infrastructure. The transport cooperation projects which have been completed or are being currently implemented include construction of an oil pipeline, eastern gas pipeline, railway bridge across the Amur (Heihe - Blagoveshchensk) and a highway bridge across the Amur (Tongjiang - Nizhneleninskoye). These projects undoubtedly contribute to the development of transport infrastructure in border regions and may serve as a platform for further economic cooperation between the two countries.

Chinese investors, such as state banks, enterprises and investment funds, show a keen interest in Russian projects associated with transport infrastructure. It is forecast that in the nearest future

\section{Chinese investment in transport infrastructural projects in Russia's Far East}

Table 3

\begin{tabular}{|c|c|c|}
\hline Investor & Sector & Planned and $\mathrm{o}$ \\
\hline $\begin{array}{l}\text { Shangdong Hi-Speed } \\
\text { Group }\end{array}$ & Motorways & $\begin{array}{l}\text { In September 2018, a concession agreement was signed for the construction and } \\
\text { operation of the road 'Khabarovsk Bypass } 13 \mathrm{~km}-42 \mathrm{~km} \text { ', involving Shangdong Hi- } \\
\text { Speed Group as a contractor. } \\
\text { The amount of potential investment in Russia in 2019-2020: } 10-20 \mathrm{bln} \text { rbs }\end{array}$ \\
\hline vay Dong- & $\begin{array}{l}\text { Railway } \\
\text { transport }\end{array}$ & $\begin{array}{l}\text { In April 2018, Far East Investment and Export Agency and China Railway Dongfang } \\
\text { Group signed an agreement of intent on financing the feasibility study of the con- } \\
\text { struction of a high-speed railroad between Suifenhe and Vladivostok. The cost of the } \\
\text { project was estimated as } 12 \text { bln US dollars. } \\
\text { In August } 2018 \text {, the Chinese side confirmed the feasibility of the project for the con- } \\
\text { struction of the } 180 \mathrm{~km} \text {-long high-speed railroad between Suifenhe and Vladivostok. } \\
\text { The amount of potential investment in Russia in 2019-2020:3-5 bln rbs }\end{array}$ \\
\hline ration & ort & $\begin{array}{l}\text { The memorandum of intent for building the bridge across the Lena was signed in } \\
\text { September } 2018 \\
\text { The project is worth } 80 \text { bln rbs. } \\
\text { The amount of potential investment in Russia in 2019-2020: } 30-40 \mathrm{bln} \text { rbs }\end{array}$ \\
\hline $\begin{array}{l}\text { China C } \\
\text { tions Co } \\
\text { Compan }\end{array}$ & $\begin{array}{l}\text { Motor } \\
\text { ports }\end{array}$ & $\begin{array}{l}\text { operation for the development of 'Primorye 1' and 'Primorye } \\
7 \text {. } \\
\text { investment in Russia in 2019-2020: } 20-40 \text { bln rbs }\end{array}$ \\
\hline $\begin{array}{l}\text { China Investment } \\
\text { Corporation (CIC) }\end{array}$ & $\begin{array}{l}\text { Railway } \\
\text { transport, } \\
\text { motorways }\end{array}$ & $\begin{array}{l}\text { ion of the railway bridge across the Amur on the border with China } \\
\text { US dollars) } \\
\text { nt of potential investment in Russia in 2019-2020: 10-20 bln rbs }\end{array}$ \\
\hline lopment & $\begin{array}{l}\text { Railway } \\
\text { transport, } \\
\text { motorways }\end{array}$ & $\begin{array}{l}\text { The framework agreement on } 8 \text { bln US dollar investment in the Far East and Siberia } \\
\text { was signed in } 2015 \text { with Vnesheconombank. } \\
\text { The amount of potential investment in Russia in 2019-2020: } 200 \text { bln rbs }\end{array}$ \\
\hline $\begin{array}{l}\text { China Railway Group } \\
\text { (CREC) }\end{array}$ & $\begin{array}{l}\text { Railway } \\
\text { transport }\end{array}$ & $\begin{array}{l}\text { Transport corridors 'Primorye-1' and 'Primorye-2' } \\
\text { The amount of potential investment in Russia in 2019-2020: } 40-60 \mathrm{bln} \text { rbs }\end{array}$ \\
\hline
\end{tabular}

Source: compiled by the author based on the analytical review of the independent Russian investment company InfraOne. 
Chinese investment in such projects will amount to $315-385$ billion roubles ${ }^{8}$. The projects indicated above are by no means the only ones. Table 3 shows the data on investors ready to invest in Russian infrastructure and the joint projects to be realized in 2019-2020. The table shows only the forecast data as companies do not specify the real amount of investment and the actual time of project completion.

Table 3 includes the data on transport infrastructural projects involving Chinese investors in Russia's Far East. It should be noted, however, that these projects are in different phases. For example, the construction of the railway bridge across the Amur is nearing completion as the bridge is expected to be put in commission in 2020. China Investment Corporation (CIC) invested 400 billion US dollars in this project. The majority of the above-described projects, however, still remain ink on paper. For instance, China Railway Construction Corporation Limited (CRCC), which was interested in constructing a bridge across the Lena near Yakutsk, had to withdraw from the project due to its high costs and insufficient feasibility. The Russian side, however, has not given up on this project. The draft documents on the transport and financial models have already been devised; the technical and operational evaluation as well as the project's organizational and legal framework are being prepared.

3. Specialist training and cooperation in the transport sphere. An important aspect of the project to connect the BRI and EAEU is specialist training, in which transport universities play a key role. Both countries need to modernize their higher education models. Universities have all the necessary resources to create international intellectual platforms for R\&D and to develop high-quality joint education courses and programs. Russian and Chinese transport universities are ready to offer their students dual diploma programs of the ' $2+3$ ' model, which means that students will be studying for two years in their home country and then 2-3 years abroad. For example, Emperor Alexander I St. Petersburg State Transport University and Beijing Transportation University have been partners since 2014 and since 2016, have been offering a dual diploma program since 2016. Talented Chinese graduates can get jobs at the largest transport enterprises in Russia and Russian graduates, in China. In 2015, the Russian-Chinese Transport Institute was established.

${ }^{8}$ Far East: Infrastructure Investment. Analytical review. Moscow, 2019, pp. 79.
Regular Sino-Russian forums, conferences and seminars in the sphere of transport and logistics create opportunities for specialists from both countries to share their experience. The annual forum of rectors of Russian and Chinese transport universities has been held since 2014. In October 2019, Beijing hosted the sixth forum of the Association of Rectors of Transport Universities of Russia and China, which involved rectors from over 60 higher education institutions in both countries. This forum can serve as an example of successful cooperation between the two countries on the state level.

Joint education and traineeship programs can help transport engineers from both countries upgrade their professional qualifications. There is every reason to believe that the hands-on approach to specialist training will enable future transport professionals to connect theoretical knowledge with practical contexts and promote transport cooperation between the two countries in the future.

\section{Conclusion}

China's fast economic growth stimulated the development of transport infrastructure, which is why it now has the most advanced railway network in the world. China is the first in the world in terms of metro construction, high-speed railway and bridge building. Apart from the use of cutting-edge technologies and the remarkable speed of construction, China is also known for its financial power. China's economic and technological progress opens vast opportunities for trustbased and mutually beneficial cooperation with Russia in the sphere of transportation.

This article was aimed at evaluating the prospects of Sino-Russian cooperation within the BRI framework. The main results of Sino-Russian partnership in the sphere of transportation are the construction of the bridge and cableway across the Amur and the international projects 'Primorye-1' and 'Primorye-2'. These projects enable both countries to significantly expand the potential of their transport infrastructure. Since the connection between the two countries is going to become faster and more comfortable, the cargo traffic and the flow of tourists are expected to grow considerably in the nearest future.

As for the priority areas in the transport sphere, especially in the context of the integration of the BRI and the EAEU, it should be noted that Chinese investors are showing keen interest in Russian regions. This can be illustrated by the 
case of 'Yamal LNG' project, which made China the leading world country in terms of natural gas imports. As of today, the majority of investment projects, however, are still a work in progress and require considerable revision in order to become economically feasible.

The China-Mongolia-Russia Economic Corridor is of particular interest as this project implies substantial modernization of the existing transport infrastructure of Mongolia ad Russia and building new international transport corridors.
As a result, the speed of freight transportation and passenger traffic flow will grow significantly, which will contribute to the economic development of the related territories. At the current stage of the project, there has been established a highway connection between Mongolia, China and Russia.

Our analysis has shown that Sino-Russian transport cooperation is now gaining momentum. Joint projects provide a solid foundation for the integration of the BRI with the EAEU.

\section{References}

Balakin, V. (2012). China's Strategy in the Arctic and Antarctica. China in Global and Regional Politics. History and Modernity, 17, 227-241. 66-81.

Bardal, A.B. (2014) Transport Interactions Between Russia and China: Far East. ECO Journal, 6,

Diayu, B. (2017), China's International Law Strategy for Participating in Arctic Affairs. Political and Legal Forum, 6, 142-153.

Dong, S., Yang, Y., Li, F., Cheng, H., Li, J., Bilgaev, A., Li, Z., \& Li, Y. (2018). An evaluation of the economic, social, and ecological risks of China-Mongolia-Russia high-speed railway construction and policy suggestions. Journal of Geographical Sciences, 28(7), 900-918. doi: 10.1007/s11442-018-1512-y

Kong, E.W., Swallow, P., \& Thomson, S.B. (2020). Belt-and-Road Initiative: Driving the need to understand intellectual capital in Chinese multinational enterprises. Thunderbird International Business Review, 279-290. 62(3), doi: 10.1002/tie.22088

Labyuk, A. (2016). The Arctic Policy of China: State and Commercial Projects. Russia and the Asia-Pacific Region, 1, 96-106.

Lazarev, V.A., \& Fisenko, A.I. (2020). Transit potential of the Northern sea route. Marine intellectual technologies, 1-2, 257-261. doi: 10.37220/MIT.2020.47.1.085

Li, Zh. (2019). Construction of the Crossborder Railway Corridor between the Eastern Parts of China and Russia. Academic Journal of North-Eastern Asia, 1, 22-35.

Lukin, A. (2020). Sino-Russian cooperation as the basis for greater Eurasia. Human Affairs-Postdisciplinary Humanities \& Social Sciences, 30(2), 174-188. doi: 10.1515/humaff-2020-0017

Mei, L. (2019). Environmental Protection Issues: Legal Path to Participate in the Regulation of Northern Sea Channels. Research on Chinese Maritime Law, 3, 60-67.

Mekhdiev, E., Pashkovskaya, I., Takmakova, E., Smirnova, O., Sadykova, K., \& Poltorykhina, S. (2019). Conjugation of the Belt and Road Initiative and Eurasian Economic Union: Problems and Development Prospects. Economies, 7(4), 1-15. doi: 10.3390/economies7040118

Nan, Y., Ya, L., \& Zhe, W. (2017). Study of the Construction of Freight Transport Corridor from Heilongjiang province to Russia. International Trade and Economic Cooperation, 6, 9-11.

Pin, L. (2015). Crossborder Checkpoints in Heilongjiang Province. Academic Journal of Russian Studies, 2, 43-51.

Ryzhova, N., \& Ioffe, G. (2009). Trans-border Exchange between Russia and China: The Case of Blagoveshchensk and Heihe. Eurasian Geography and Economics, 50(3), 348-364.

Sazonov S.L., \& Xiao, C. (2018), Analysis of the Creation of the Chinese-Russian and Eurasian Transport Corridor. Issledovanie Sibiri, 5, 30-38.

Shuan, L, Yujun, M., \& Jianping, Zh. (2017). Research and Analysis of Infrastructure Construction in Border Regions of China and Russia. Eurasian Economics, 1, 66-73.

Tjia, Y.-n.L. (2020). The Unintended Consequences of Politicization of the Belt and Road's China-Europe Freight Train Initiative. China Journal, 83, 58-78. doi: $\underline{10.1086 / 706743}$

Wang, C., Lim, M.K., Zhang, X., Zhao, L., \& Lee, P.T.-W. (2020). Railway and road infrastructure in the Belt and Road Initiative countries: Estimating the impact of transport infrastructure on 
economic growth. Transportation Research Part A-Policy and Practice, 134, 288-307. doi: 10.1016/j. tra.2020.02.009

Xin, Z. (2018). Study of the Application of Laws of Freight Transportation Along the Heilong Jiang- Amur River within the Framework of the Belt and Road Initiative. Journal of Dalian Maritime University (Social Sciences), 2, 9-21.

Yi, J. (2017). Reflections on the Economic Development of Crossborder Points in China and Russia. Eurasian Economy, 6, 2-15.

Yinan, J. (2019). Multilateral Cooperation within the 'Ice Silk Road' Project: Opportunities, Challenges and Ways of Development. Pacific Journal, 8, 67-77.

Yunhao, Z. (2015), The State and Challenges of Sino-Russian Railway Transport Corridor, Academic Journal of Russian Studies, 1, 46-50.

Zeng, Q., Lu, T., Lin, K.-C., Yuen, K.F., \& Li, K.X. (2020). The competitiveness of Arctic shipping over Suez Canal and China-Europe railway. Transport Policy, 86, 34-43. doi: 10.1016/j.tranpol.2019.11.005

\section{Information about the author}

Qiujie Chen - Researcher, Institute of Russia, Harbin Academy of Social Sciences of Heilongjiang Province (150018, China, Harbin, Yui, 501); e-mail: 284748191@qq.com

ARTICLE INFO: received November 28, 2019; accepted April 15, 2020

\section{Информация об авторе}

Чэнь Цюцзе - научный сотрудник Института России Академии общественных наук провинции Хэйлунцзян (150018, КНР, г. Харбин, ул. Юи, 501); e-mail: 284748191@qq.com

ИНФОРМАЦИЯ О СТАТЬЕ: дата поступления 28 ноября 2019 г.; дата принятия к печати 15 апреля 2020 г. 